\title{
POTENSI EKSTRAK BUAH LIBO (Ficus variegate, Blume ) SEBAGAI HEPATOPROTEKTOR PADA TIKUS (Rattus novergicus)

\author{
Halimatu Sadiyah $^{1, \dagger}$, Mukti Priastomo ${ }^{1}$, Rolan Rusli ${ }^{1,2, \ddagger}$ \\ ${ }^{1}$ Laboratorium Penelitian dan Pengembangan Kefarmasian "Farmaka Tropis", \\ Fakultas Farmasi, Universitas Mulawarman, Samarinda, Indonesia \\ †Email: limsadiyah2@gmail.com \\ ${ }^{2}$ Kelompok Bidang Ilmu Kimia Farmasi, Fakultas Farmasi, \\ Universitas Mulawarman, Samarinda, Indonesia \\ *Email: rolan@farmasi.unmul.ac.id
}

\begin{abstract}
ABSTRAK
Buah libo (Ficus variegate, Blume) mengandung metabolit sekunder alkaloid, saponin, flavanoid dan polifenol dimana hal tersebut menunjukkan bahwa buah libo memiliki aktivitas antioksidan yang dapat berperan dalam pencegahan dan terapi berbagai penyakit termasuk kerusakan hepar. Penelitian ini bertujuan mengetahui potensi hepatoprotektor dan dosis efektif ekstrak buah libo pada tikus dibandingkan dengan curcuma ${ }^{\circledR}$ melalui indikator SGOT dan SGPT serta perubahan berat badan. Jenis penelitian ini eksperimental laboratorik. Subjek penelitian 12 ekor tikus dalam 4 kelompok perlakuan. Data dianalisis menggunakan uji One-Way Anova. Hasil yang diperoleh adalah terdapat perbedaan yang signifikan kadar SGOT dan SGPT.
\end{abstract}

Kata Kunci: Buah libo, Antioksidan, Hepatoprotektor, SGOT, SGPT.

DOI: https://doi.org/10.25026/mpc.v9i1.343

\section{PENDAHULUAN}

Hati merupakan organ terbesar di dalam tubuh manusia yang berfungsi sebagai tempat untuk metabolisme lemak, karbohidrat, dan protein, sebagai tempat detoksifikasi senyawa yang bersifat toksin, pembentukan dan ekskresi garam empedu, dan fungsi vaskular [1].

Risiko terjadinya penyakit hepar semakin meningkat seiring dengan bertambah luasnya penggunaan senyawa yang bersifat hepatotoksik. Senyawa hepatotoksik tersebut berasal dari penyalahgunaan obat-obatan, alkohol, dan zat toksik lainnya [2]. Hepar menjadi organ yang paling rawan mengalami kerusakan oleh senyawa toksik [3]. Hepar memiliki kemampuan regenerasi yang tinggi, namun pada gangguan yang berat kerusakan hepar akan berakibat fatal [4]. Salah satu contoh obat yang dapat menimbulkan kerusakan hepar adalah paracetamol [5].

Pada keadaan overdosis parasetamol, mekanisme sulfat dan glukoronat konjugase menjadi jenuh sehingga tejadi peningkatan parasetamol yang dihidroksilasi oleh sitokrom P-450 membentuk N-asetil-p-benzokuinon imin (NAPQI). Peningkatan kecepatan dan jumlah pembentukkan NAPQI melampaui persediaan dan regenerasi 
glutation (GSH) sehingga terjadi deplesi GSH seluler [6]. Deplesi GSH menyebabkan NAPQI bebas berikatan secara kovalen dengan makromolekul sel hepar serta menyebabkan kerusakan dan kematian sel hepar, sehingga sel hepar lebih rentan terhadap stres oksidatif dan peroksidasi lipid [7] dan akhirnya menyebabkan nekrosis hepar akut [8].

Kerusakan sel hepar menyebabkan keluarnya enzim-enzim hepar intrasel dari sitosol dan organela menuju sinusoid-sinusoid sehingga menyebabkan kadar enzim tersebut dalam darah meningkat. Salah satu enzim yang merupakan indikator spesifik kerusakan hepar adalah SGPT dan SGOT [9].

Sampai saat ini belum ada terapi adekuat untuk mencegah dan mengobati penyakit hepar. Berbagai obat baru telah dikembangkan namun obat-obat tersebut seringkali menimbulkan efek samping yang tidak diinginkan dan seringkali terlalu mahal, terutama bagi negara berkembang. Hal itu menyebabkan masyarakat beralih ke pengobatan herbal karena dianggap lebih alami, mudah diperoleh, dan telah digunakan secara turun-temurun. Oleh karena itu, riset ilmiah mengenai efek hepatoprotektif herbal dapat memberikan manfaat sebagai salah satu terapi penyakit hepar [10].

Berbagai tumbuhan menunjukkan efek antioksidan yang berperan penting dalam pencegahan dan terapi berbagai penyakit termasuk kerusakan hepar [3]. Salah satu tumbuhan yang memiliki kandungan antioksidan tinggi adalah buah libo. Dari beberapa penelitian sebelumnya membuktikan bahwa tumbuhan tersebut memiliki kandungan antioksidan tinggi yang dapat mencegah stress oksidatif dan menangkal radikal bebas. Sampai saat ini belum ada penelitian mengenai potensi dari ekstrak buah libo sebagai hepatoprotektor. Berdasarkan hal tersebut Penelitian ini dilakuan untuk mengetahui potensi hepatoprotektor dan dosis efektif ekstrak buah libo pada tikus dibandingkan dengan curcuma ${ }^{\circledR}$ melalui indikator SGOT dan SGPT serta perubahan berat badan.

\section{METODE PENELITIAN}

\begin{abstract}
Alat
Alat-alat yang digunakan adalah toples maserasi, rotary evaporator, corong buchner, mangkok, timbangan analitik, timbangan hewan, kandang hewan, lumpang dan stamfer, sonde oral, spatel, beaker glass, pipet tetes,labu ukur, corong kaca, alat-alat bedah (gunting, pinset, kapas), kaca arloji, batang pengaduk, spuid $3 \mathrm{~mL}$.
\end{abstract}

\section{Bahan}

Bahan yang digunakan adalah buah libo, etanol $96 \%$, aquadest, natrium carboxcy methyl cellulosa (Na CMC), tablet paracetamol, tablet curcuma ${ }^{\circledR}$, makanan dan minum standar tikus, formalin buffer $10 \%$, kertas saring, plastik wrap, alkohol $70 \%$, n-heksan.

\section{Prosedur Kerja}

\section{Penyiapan dan Pengolahan Sampel}

Bahan penelitian berupa buah libo (Ficus variegate, Blume) berasal dari Samarinda, Kalimantan Timur. Pengambilan tumbuhan ini dilakukan dengan cara mengambil seluruh bagian buah dari tanaman kemudian dilakukan pencucian dengan air mengalir. Seluruh bagian buah yang telah bersih dipotongpotong kecil dan dioven pada suhu $50{ }^{\circ} \mathrm{C}$ selama 2 hari. Simplisia buah libo (Ficus variegate Blume.) dihaluskan dan ditimbang sebanyak 431,8 gram dimasukkan dalam wadah meserasi, tambahkan $\mathrm{n}$-heksana hingga simplisia tersebut terendam untuk menghilangkan getah dari buah tersebut selama 3 hari [12-21]. Kemudian disaring n-heksana, dan ditambahkan etanol $96 \%$ hingga simplisia tersebut terendam selama 3 hari dalam toples kaca tertutup dan terlindung 
dari cahaya sambil berulang-ulang diaduk setiap 24 jam sekali. Setelah 3 hari simplisia di saring. Hasil penyarian yang didapat kemudian dikumpulkan dan diuapkan hingga diperoleh ekstrak etanol yang kental.

\section{Penyiapan dan Perlakuan Hewan Uji}

Hewan uji yang digunakan dalam penelitian ini adalah tikus putih (Rattus norvegicus) sehat dengan bobot badan rata-rata 150-200 g. Dimana hewan uji ini diadaptasikan selama 2 minggu. Hewan uji yang digunakan sebanyak 12 ekor tikus dibagi atas 4 kelompok yaitu. Kelompok I kontrol negatif (suspensi NaCMC 0,5\%), kelompok II kontrol positif (suspensi curcuma ${ }^{\circledR}$ ), Kelompok III ekstrak buah libo (dosis $100 \mathrm{mg} / \mathrm{kgBB}$ ). kelompok IV buah libo (dosis 200 $\mathrm{mg} / \mathrm{kgBB}$ ). Paracetamol yang digunakan ialah dengan dosis $2000 \mathrm{mg} / \mathrm{kgBB}$ yang dilarutkan menggunakan Na-CMC.

Perlakuan yang diberikan secara oral menggunakan sonde lambung khusus untuk tikus. Sebelum diberi perlakuan hewan uji terlebih dahulu dipuasakan selama 5-8 jam. Kemudian sampel darah diambil melalui vena lateralis ekor. Darah ditampung dan disentrifuge kemudian serum darah diukur kadar SGOT dan SGPT (sebagai nilai normal) dengan menggunakan human analyzer. Setelah itu semua kelompok perlakuan diberikan sesuai perlakuan selama 7 hari selanjutnya diberikan suspensi parasetamol dari hari ke 8 sampai hari ke 14 dan perlakuan tetap dilanjutkan. Pada hari ke 15 dilakukan pengambilan darah dan pengukuran SGOT/SGPT setelah di terapi.

\section{Analisis data \\ Data diolah dengan menggunakan program komputer SPSS 22.0 for windows, dengan uji komparatif menggunakan uji statistik One way ANOVA pada pengukuran kadar SGPT dan SGOT.}

\section{HASIL DAN PEMBAHASAN}

\section{Hasil Ekstraksi}

Ekstrak buah libo dibuat dengan cara maserasi menggunakan etanol $96 \%$. Hasil ekstraksi pada penelitian ini diperoleh ekstrak etanol kental buah libo sebanyak 21,2 gram dengan rendemen sebesar $4,9 \%$.

\section{Berat Badan Tikus}

Selama masa perlakuan semua hewan coba dilakukan pengukuran berat badan hewan coba pada awal dan akhir masa perlakuan. Data pengukuran berat badan dapat dilihat pada Gambar 1 .

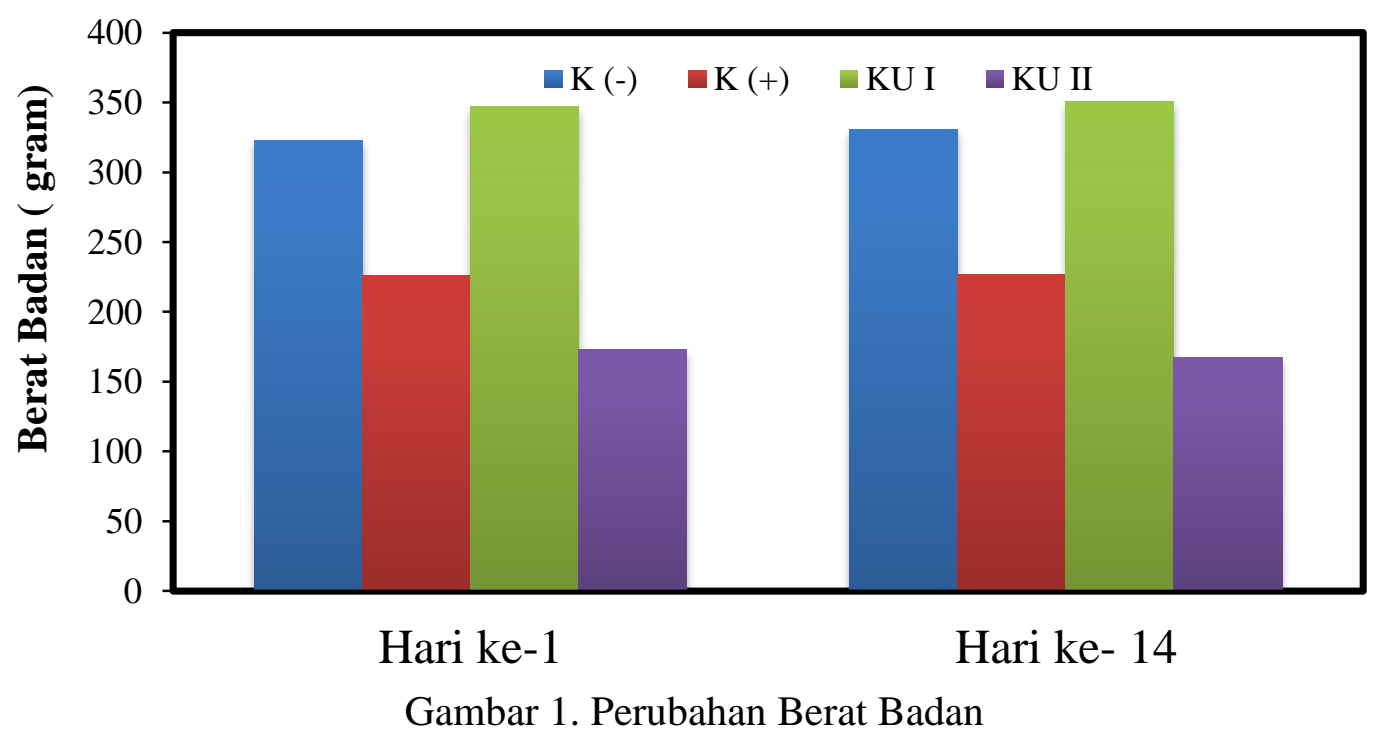


Berdasarkan data perubahan berat badan selama masa perlakuan, semua kelompok tikus rata-rata mengalami kenaikan berat badan antara 1-8 gram. Pengamatan yang dilakukan terhadap perubahan berat badan digunakan untuk memantau perkembangan hewan coba selama masa perlakuan serta meminimalisir terjadinya kematian selama masa perlakuan. Penimbangan berat badan juga bertujuan sebagai acuan untuk menghitung dosis pemberian perlakuan serta untuk mengetahui volume pemberian pada tikus

\section{Pengukuran Kadar SGOT dan SGPT}

Hati merupakan organ terbesar di dalam tubuh manusia yang berfungsi sebagai tempat untuk metabolisme lemak, karbohidrat, dan protein, sebagai tempat detoksifikasi senyawa yang bersifat toksin, pembentukan dan ekskresi garam empedu, dan fungsi vaskular [1]. Hepar menjadi organ yang paling rawan mengalami kerusakan oleh senyawa toksik [3]. Hepar memiliki kemampuan regenerasi yang tinggi, namun pada gangguan yang berat kerusakan hepar akan berakibat fatal [4].

Pada penelitian ini, paracetamol digunakan sebagai induktor kerusakan hati. Pada keadaan overdosis parasetamol, mekanisme sulfat dan glukoronat konjugase menjadi jenuh sehingga tejadi peningkatan parasetamol yang dihidroksilasi oleh sitokrom P-450 membentuk N-asetil-p- benzokuinon imin (NAPQI). Peningkatan kecepatan dan jumlah pembentukkan NAPQI melampaui persediaan dan regenerasi glutation (GSH) sehingga terjadi deplesi GSH seluler [6]. Deplesi GSH menyebabkan NAPQI bebas berikatan secara kovalen dengan makromolekul sel hepar serta menyebabkan kerusakan dan kematian sel hepar, sehingga sel hepar lebih rentan terhadap stres oksidatif dan peroksidasi lipid [7] dan akhirnya menyebabkan nekrosis hepar akut [8]. Kerusakan sel hepar menyebabkan keluarnya enzim-enzim hepar intrasel dari sitosol dan organela menuju sinusoid-sinusoid sehingga menyebabkan kadar enzim tersebut dalam darah meningkat.

Antioksidan yang terdiri dari flavonoid, alkaloid, saponin dan polifenol menunjukan aktivitas antioksidatif dimana tumbuhan yang memiliki antioksidan yang tinggi dapat mencegah strees oksidatif dan menangkal radikal bebas. Flavanoid meruapakan salah satu senyawa antioksidan yang berfungsi menghambat proses biotransformasi paracetamol menjadi senyawa yang lebih toksik. Salah satu gugus $\mathrm{OH}$ pada senyawa flavanoid akan menggantikan glutation (GSH) yang telah terdeplesi oleh radikal bebas akibat pemberian paracetamol dosis toksik. Gugus $\mathrm{OH}$ pada flavanoid akan membantu konjugasi paracetamol menjadi asam merkapturat dan mengubah metabolit reaktif paracetamol hasil metabolisme sitokrom P-450 yaitu N-acetyl pbenzoquinonimine (NAPQI) menjadi metabolit non-aktif yang bersifat hidrofilik sehingga mudah dieksresikan melalui urin.

Penelitian ini dilakukan dengan membagi hewan percobaan menjadi 4 kelompok. Keempat kelompok tersebut yaitu kelompok kontrol negatif, kontrol positif, dosis $100 \mathrm{mg} / \mathrm{kgBB}$ dan 200 $\mathrm{mg} / \mathrm{kgBB}$. Pada hari 1-7 kelompok kontrol positif diberikan suspense curcuma dan negatif hanya diberikan Na.CMC $\quad 0,5 \%$ sedangkan kelompok dosis diberikan paracetamol dosis 2000 $\mathrm{mg} / \mathrm{kgBB}$ diberikan pada hari ke 8 terhadap semua kelompok. Pemberian perlakuan sebelum induksi bertujuan untuk melihat apakah perlakuan yang diberikan tersebut dapat mencegah terjadinya kerusakan hati hewan uji. Pemeriksaan aktivitas SGPT dan SGOT dilakukan pada hari ke 0 dan hari ke 15 . 
Tabel 2. Hasil pengukuran kadar SGOT dan SGPT

\begin{tabular}{ccccc}
\hline \multirow{2}{*}{ Kelompok } & \multicolumn{2}{c}{ Awal } & \multicolumn{2}{c}{ Akhir } \\
\cline { 2 - 5 } & $\begin{array}{c}\text { SGOT } \\
\text { (U/l) }\end{array}$ & $\begin{array}{c}\text { SGPT } \\
\text { (U/1) }\end{array}$ & $\begin{array}{c}\text { SGOT } \\
(\mathrm{U} / \mathrm{l})\end{array}$ & $\begin{array}{c}\text { SGPT } \\
(\mathrm{U} / \mathrm{l})\end{array}$ \\
\hline Negatif & 92 & 61 & 119 & 75 \\
Positif & 93 & 52 & 94 & 46 \\
Uji 1 & 89 & 52 & 145 & 72 \\
Uji 2 & 120 & 55 & 133 & 54 \\
\hline
\end{tabular}

Pada hasil pengukuran SGOT pada semua kelompok pada pengukuran pretest masih dalam kadar yang rendah kemudian mengalami peningkatan pada saat pengukuran posttest atau setelah dilakukan terapi. Hasil pengukuran SGPT pada semua kelompok pada pengukuran prestest memiliki kadar SGPT yang rendah namun pada saat pengukuran posttest didapatkan bahwa pada kelompok negative mengalami kenaikan kadar SGPT hal tersebut dikarenakan pada kontrol negative hanya diberikan suspensi Na-CMC $0,5 \%$ kemudian diinduksi paracetamol sehingga dapat disimpulkan bahwa pemberian paracetamol dosis 2000 $\mathrm{mg} / \mathrm{kgBB}$ dapat menimbulkan kerusakan hati yang ditandai dengan peningkatan kadar SGOT dan SGPT. Pada kelompok kontrol positif hasil pengukuran kadar SGPT yang didapatkan adalah adanya penurunan nilai SGPT hal tersebut disebabkan karena kontrol positif yang diberikan adalah Curcuma ${ }^{\circledR}$ dengan dosis $20 \mathrm{mg}$ dimana obat tersebut merupakan obat yang memiliki mekanisme sebagai hepatoprotektor. Sedangkan nilai SGPT pada perlakuan dosis didapatkan pada dosis $100 \mathrm{mg} / \mathrm{kgBB}$ terjadi peningkatan SGPT dimana dosis $100 \mathrm{mg} / \mathrm{kgBB}$ dari penelitian sebelumnya merupakan dosis terbaik sebagai antidiare namun pada hasil penelitian ini pada dosis 100 $\mathrm{mg} / \mathrm{kgBB}$ dapat meningkatkan kadar SGOT dan SGPT yang berarti pada dosis tersebut tidak memiliki potensi sebagai hepatoprotektor. Sedangkan pada dosis $200 \mathrm{mg} / \mathrm{kgBB}$ dapat menurunkan nilai
SGPT atau nilai SGPT tetap dalam keadaan normal yang berarti pada dosis tersebut memiliki potensi sebagai hepatoprotektor tetapi efeknya lebih kecil dibandingkan curcuma ${ }^{\circledR}$.

Pada penelitian sebagai indikator kerusakan hati adalah kadar enzim SGPT. Enzim SGPT merupakan indikator yang sensitif dalam mengenali adanya penyakit pada hati yang bersifat akut. Hal ini disebabkan hepatosit yang rusak atau mati akan melepaskan enzim SGPT ke dalam aliran darah [9]. Enzim SGPT merupakan enzim yang lebih dipercaya dibandingkan SGOT dalam menentukan kerusakan sel hati. Hal ini disebabkan SGPT banyak ditemukan terutama di hati sedangkan SGOT dapat ditemukan selain di hati, seperti di otot jantung, otot rangka, ginjal, pankreas, otak, sel darah merah, dan sel darah putih. Dengan demikian, jika hanya terjadi peningkatan SGOT maka dapat saja yang mengalami kerusakan adalah sel-sel organ lainnya yang mengandung SGOT [11]. Dari hasil uji statistik One Way ANOVA menunjukkan terdapat perbedaan yang signifikan kadar SGOT dan SGPT.

\section{KESIMPULAN}

Dari penelitian yang telah dilakukan diperoleh kesimpulan bahwa ekstrak buah libo memiliki potensi sebagai hepatoprotektor karena dapat menurunkan aktivitas SGPT pada tikus yang diinduksi paracetamol dengan dosis yang efektif adalah dosis $200 \mathrm{mg} / \mathrm{kg}$ BB tetapi efeknya lebih kecil dibandingkan curcuma ${ }^{\circledR}$. Dari hasil uji statistik One Way ANOVA menunjukkan terdapat perbedaan yang signifikan kadar SGOT dan SGPT.

\section{DAFTAR PUSTAKA}

[1] Wahyuningsih, S.and Sutjiatmo, A. B. (2015). Uji Aktivitas Hepatoprotektor Ekstrak Air Akar Kuning ( Fibraurea tinctoria Lour) Pada Tikus Putih Betina Galur Wistar. Aristoteles, 4(1). 
[2] Devaraj, S., Ismail, S., Ramanathan, S., Marimuthu, S., Fei, Y.M. 2010. Evaluation of the hepatoprotective activity of standardized ethanolic extract of Curcuma xanthorrhiza Roxb. Journal of Medicinal Plants Research. Vol 4(23. pp. 2512 - 2517.

[3] Farghaly, H.S. and M.A. Hussein, 2010. Protective effect of curcumin against paracetamol-induced liver damage. Aust. J. Basic Applied Sci., 4: 4266-4274.

[4] Guyton dan Hall. 2009. Textbook of Medical Physiology. Philadelphia: W.B.Saunders.

[5] Mehta Astha, Ginpreet Kaur, Meena Chintamaneni (2012). Piperine and Quercetin enhances antioxidant and hepatoprotective effect of Curcumin in paracetamol induced oxidative stress. Int Journal of Pharmacology, 8(2): 101-107.

[6] Furst D.E. \& Munster T. 2002. Obatobat anti inflamasi nonsteroid, obatobat antireumatik pemodifikasi penyakit, analgesik nonopioid, dan obat-obat untuk pirai. Dalam: Katzung B.G., ed. Farmakologi dasar dan klinik. Edisi 8. Jakarta: Salemba Medika.

[7] James LP, McCullough SS, Lamps LW, Hinson JA. Effect of $N$ acetylcysteine on acetaminophen toxicity in mice: relationship to reactive nitrogen and cytokine formation. Toxicol. Sci. 2003;75:458-467.

[8] Farrel MK, Buenvalor JC. Sistemic disease and the liver. Dalam :Sucky FJ, penyunting. Liver disease in children. St. Louis : Mosby, 1994. H. 580-97.

[9] Chopra, S. 2001. The Liver Book: A Comprehensive Guide to Diagnosis, Treatment, and Recovery. New York: Pocket Books, Simon \& Schuster, Inc.

[10] Gini C. Kuriakose and Muraleedhara G. Kurup, 2010. Hepatoprotective effect of Spirulina lonar on paracetamol induced liver damage in rats. Asian journal biology science. 1(3), 614-623.

[11] Sari,W., Indrawan, L. \& Djing O,G. 2008. Care Yourself, Hepatitis. Depok: Penebar Plus.

[12]Ningsih, B. A., Rahmadani, A., Fadraersada, J., \& Rusli, R. (2016). Proceeding of Mulawarman Pharmaceuticals Conferences, 3(2), 114-120.

[13]R Rusli, BA Ningsih, A Rahmadani, L Febrina, V Maulidya, J Fadraersada. 2019. Isolation and Antioxidant and Antibacterial Activity of Flavonoid from Ficus variegate Blume. Indonesian Journal of Chemistry. 19 (2), 538-543.

[14] Syamsidar, S., Mita, N., \& Rusli, R. (2017). Proceeding of Mulawarman Pharmaceuticals Conferences, 6(1), 98-104.

[15] Sugipratiwi, U., Maulidya, V., \& Rusli, R. (2016). Proceeding of Mulawarman Pharmaceuticals Conferences, 4(1), 372-376.

[16] Toding, M., Fridayanti, A., Ayu, W. D., \& Rusli, R. (2016). Proceeding of Mulawarman Pharmaceuticals Conferences, 4(1), 193-199.

[17]Ping, T. J., Rusli, R., \& Gama, S. I. (2016). Proceeding of Mulawarman Pharmaceuticals Conferences, 4(1), 356-363.

[18] Aulia, I., Ayu, W. D., \& Rusli, R. (2016). Proceeding of Mulawarman Pharmaceuticals Conferences, 4(1), 154-161.

[19]Prisukarno, B., Fridayanti, A., Gama, S. I., \& Rusli, R. (2018). Proceeding of Mulawarman Pharmaceuticals Conferences, 7(1), 37-40.

[20]Zakaria B.A., M. R., Febrina, L., \& Rusli, R. (2017). Proceeding of Mulawarman Pharmaceuticals Conferences, 6(1), 185-190.

[21] Ntowe, D., Rahmadani, A., Fridayanti, A., \& Rusli, R. (2016). Proceeding of Mulawarman Pharmaceuticals Conferences, 3(2), 156-159. 